\title{
KEBIJAKAN BELT AND ROAD INITIATIVE SEBAGAI ALAT SOFT POWER CINA DALAM MEMBANGUN HEGEMONI DI KAWASAN ASIA TENGGARA (STUDI KASUS: INVESTASI CINA DI INDONESIA)
}

\author{
Gerald Theodorus L.Toruan \\ Universitas Pertahanan \& Balitbang Kemhan \\ theodorus_recht@yahoo.com
}

\begin{abstract}
China is currently in an effort to build a new power in the world, through the Chinese Belt and Road Initiative in the era of President Xi Jinping, providing investment assistance to Southeast Asian countries. This investment is given in order to build Chinese hegemony in Southeast Asia. One of the countries in Southeast Asia that is co-financed by China is Indonesia, by prioritizing Indonesia's national interests in cooperation with China in infrastructure development in Indonesia. This research used qualitative methode research with a case study approach, while the data collected through literature study. The final conclusion of this research is that China's BRI program in Indonesia must continue to prioritize national interests and also the sovereignty of the Indonesian state, Indonesia should not be sold like the country of Sri Lanka.
\end{abstract}

Keywords: Belt and Road Initiative, Cina Investation Hegemony, Soft Power.

Abstrak - Cina saat ini sedang dalam upaya membangun kekuatan baru di dunia, melalui kebijakan Belt and Road Initiative Cina di era Presiden Xi Jinping banyak memberikan bantuan investasi ke negaranegara Asia Tenggara. Pemberiaan investasi ini dalam rangka membangun hegemoni Cina di kawasan Asia Tenggara. Indonesia adalah salah satu negara di Asia Tenggara yang ikut dibiayai Cina dengan mengedepankan kepentingan nasional Indonesia bekerjasama dengan Cina dalam pembangunan infrastruktur di Indonesia. Penelitian yang digunakan adalah penelitian kualitatif dengan pendekatan studi kasus, adapun penulis mengumpulkan data melalui studi pustaka. Kesimpulan dari penelitian ini adalah program BRI Cina di Indonesia haruslah tetap mengedepankan kepentingan nasional dan juga kedaulatan negara Indonesia, Indonesia jangan sampai terjual seperti negara Srilanka.

Kata kunci : Belt and Road Initiative, Hegemoni, Investasi Cina, Soft Power.

\section{PENDAHULUAN}

Cina dalam beberapa tahun belakangan ini khususnya lima tahun ke belakang berubah menjadi negara yang memiliki misi untuk menguasai dunia. Kebangkitan Cina saat ini dipandang dalam rangka upaya menandingi kekuatan major power di dunia, yaitu Amerika Serikat dan Rusia. Transformasi Cina menjadi salah satu negara besar di dunia didukung pula dengan kebijakan luar negeri negaranya. Pada masa kepemimpinan Presiden Xi Jinping Cina bangkit menjadi kekuatan ekonomi dunia yang semakin tak tertandingi. Salah satu strategi kebijakan pembangunan ekonomi terkemuka yang dilancarkan oleh Presiden Xi Jinping adalah "One Belt One Road" (OBOR) yang bertransformasi menjadi Belt Road Initiative (BRI). Strategi ini terbentuk berdasarkan inspirasi jalur perdagangan yang bersifat tradisional dan dikenal sebagai Jalur Sutra (Silk Road) di masa lalu (Bambang Cipto, 2018:26). Berikut ini adalah peta Belt Road Initiative yang digaungkan oleh Cina. 
Gambar 1. Peta Belt Road Initiative Cina

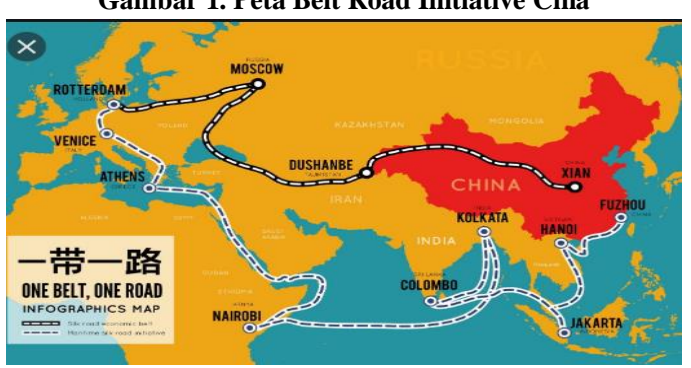

Sumber: katadata.co.id, 2020

Kebijakan OBOR ini merupakan salah satu proyek raksasa Cina yang melintasi 3 (tiga) benua, yaitu benua Asia, benua Eropa dan benua Afrika. Jika proyek ini sukses dijalankan, proyek OBOR merupakan inisiatif paling ambisius yang pernah digagas oleh satu pemerintahan di era kontemporer ini, karena akan melibatkan sejumlah 65 negara di tiga benua dengan total populasi sekitar 4,4 miliar orang (Kurniawan, 2016 dalam Handriyanto Wijaya, 2020).

Belt Road Initiative bertujuan untuk peningkatan jaringan global, antara negara maju dengan negara berkembang. BRI fokus kepada penguatan jaringan yang memudahkan aliran perdagangan bebas menjadi efisien dan produktif serta mengintegrasikan lebih lanjut di pasar internasional, baik secara fisik maupun digital (Sindy Y.Fitri \& Dairatul Ma'arif, 2019).

Menteri Luar Negeri Cina Wang Yi pada tanggal 15-18 Oktober 2020 saat berkunjung ke empat negara di Asia Tenggara, dalam kunjungan ke negara Kamboja, Laos, Thailand dan Malaysia, Menlu Wang menempatkan Cina sebagai negara mitra bagi ke 4 negara tersebut dan ingin membantu negara tersebut mengembangkan kerja sama ekonomi (Ludiro Madu, 2020 dalam Geotimes 2020).

Tujuan yang ingin dicapai oleh Presiden $\mathrm{Xi}$ Jinping melalui kebijakan BRI adalah ingin membangkitkan kembali masa kejayaan yang pernah dicapai
Cina melalui jalur sutra di masa lampau.Tidak hanya itu, melalui BRI Presiden $\mathrm{Xi}$ Jinping juga ingin membawa kebangkitan China ke arah negara yang kuat dibandingkan dengan negara lain di masa yang akan datang sesuai dengan impiannya seperti tertuang di Chinesse Dream (Li, 2015). Program Belt Road Initiative saat ini mengarah kepada kawasan Asia Tenggara, di kawasan ini Cina berusaha membangun hegemoninya dan juga mencoba merebut simpati negaranegara Asia Tenggara dari negara pesaingnya yaitu Amerika Serikat.

Kawasan Asia Tenggara adalah mitra strategis penting dalam program BRI Cina, kawasan ini berfungsi sebagai penghubung utama jalur sutera maritim yang memiliki tujuan sebagai penghubung Pantai Cina dengan Asia Selatan, Timur Tengah, dan benua Eropa melewati Laut Cina Selatan dan Samudera Hindia.

Berdasarkah hasil sebuah studi 2018 oleh Oxford Economics dan CIMB ASEAN Research Institute, proyekproyek BRI di negara-negara ASEAN berjumlah lebih dari $\$ 739$ miliar. Indonesia adalah rumah bagi total investasi BRI tertinggi sebesar \$171 miliar, diikuti Vietnam (\$152 miliar), Kamboja (\$104 miliar), Malaysia (\$98,5 miliar), Singapura (\$70,1 miliar), Laos (\$48 miliar), Brunei (\$36 miliar), Myanmar (27,2 miliar) dan Filipina (\$9,4 miliar) (Phidel Vineles, 2019 dalam Matamata Politik, 2019).

Belt and Road Initiative merupakan salah satu strategi soft power Cina di kawasan Asia Tenggara. Strategi ini digunakan dalam rangka menandingi negara besar seperti Amerika Serikat yang telah lebih dahulu menancapkan hegemoninya di kawasan Asia Tenggara.

Cina di masa Presiden Ji Xinping saat ini berupaya untuk menghilangkan 
stigma negara yang komunis di kawasan Asia Tenggara dengan merekonstruksi ulang dengan jalan menjalin hubungan baik dengan negara-negara Asia Tenggara terhadap Cina menggunakan diplomasi "soft power" (Kyoto Review, 2014).

Melihat bahwa kawasan Asia Tenggara dipandang penting saat ini oleh negara besar, khususnya Cina dan membuat Cina banyak menginvestasikan anggarannya di kawasan Asia Tenggara melalui program Belt and Road Initiative, maka penulis melakukan penelitian yang dipandang sangat relevan saat ini dengan judul Kebijakan Belt and Road Initiative Sebagai Alat Soft Power Cina Dalam Membangun Hegemoni di Kawasan Asia Tenggara (Studi Kasus: Investasi Cina di Indonesia).

Batasan dalam penelitian ini adalah negara Indonesia sebagai bagian dari kawasan Asia Tenggara, dan fokus dari penelitian ini adalah kebijakan Belt and Road Initiative di Indonesia.

\section{METODE PENELITIAN}

Peneliti menggunakan metode penelitian kualitatif dengan pendekatan deskriptif. Adapun tekhnik pengumpulan data penulis adalah menggunakan studi pustaka (library research).

Penelitian kualitatif lebih banyak penekanan kepada analisis proses berpikir induktif yang ada kaitannya dengan dinamika hubungan antar fenomena yang diamati, dan senantiasa menggunakan logika ilmiah. Metode kualitatif memiliki tujuan untuk pengembangan konsep sensitivitas pada masalah yang dihadapi, menerangkan realitas yang berkaitan dengan penelusuran teori dari bawah (grounded theory) dan mengembangkan pemahaman akan satu atau lebih dari fenomena yang dihadapi (Gunawan, 2013).

Penelitian kualitatif merupakan penelitian interpretif, yang di dalamnya peneliti terlibat secara langsung dengan penelitiannya yang berkelanjutan dan terus menerus dengan para informan (Creswell, 2017: 264)

Tekhnik pengumpulan data dalam penelitian ini adalah melalui library research, library research melibatkan proses langkah demi langkah yang digunakan dalam mengumpulkan informasi untuk menulis makalah, membuat presentasi, atau menyelesaikan proyek peneliti tertentu ( Bungin, 2020: 232). Proses library research sendiri meliputi mengidentifikasi dan menemukan informasi yang relevan, menganalisis apa yang peneliti temukan, dan kemudian mengembangkan serta mengekspresikan ide-ide peneliti (Bungin, 2020: 232).

\section{HASIL DAN PEMBAHASAN}

Belt and Road Initiative (BRI) Cina.

Belt and Road Initiative pertama kali diinisiasi oleh Presiden Xi Jinping di tahun 2011, program ini merupakan ambisi besar di era kepemimpinannya. Tujuan program ini adalah untuk memperkuat jaringan infrastruktur, perdagangan, dan investasi antara Cina dengan negara-negara berkembang lain secara bersama-sama khususnya benua Eropa dan Asia (Eurasia) dan 3/4 (Peter Cai, 2017 Maret) sumber energi dengan target 4.4 milliar dari 30\% PDB global, $63 \%$ dari total populasi global (Bannati Khairani, et.al 2019).

Istilah belt sendiri memiliki makna kepada mengenai serangkaian jalan darat, jalur pipa, kereta api dan infrastruktur lainnya melalui Asia Tengah, sampai ke benua Eropa. Sedangkan istilah Road mengacu kepada serangkaian pelabuhan dan 
jalur-jalur perdagangan maritim yang masuk melalui Laut Cina dan Samudera Hindia ke Timur Tengah, pantai timur Afrika dan seterusnya sampai dengan benua Eropa (Shatz, 2016 dalam Handriyanto Wijaya, 2020).

Kebijakan Belt and Road Initiative dibuat oleh Republik Rakyat Cina adalah berdasarkan nilai historis, empiris dan praktis. Menurut sejarah berdirinya Cina bahwa jalur perdagangan ini telah ada sejak berabad-abad lalu. Melalui kebijakan ini Presiden $\mathrm{Xi}$ Jinping ingin mencoba kembali jalur sutera tersebut.

Presiden Xi Jinping menegaskan bahwa program ini akan menjadi fokus kebijakan luar negeri pada era kepemimpinannya dan menjadi diplomasi ekonomi bagi Cina (Wei, 2016), dengan demikian menunjukkan kebijakan ini digunakan sebagai alat soft power dalam kebijakan luar negeri Cina kepada negara-negara di benua Asia dalam beberapa tahun ke depan.

Belt and Road Initiative Cina memiliki dua rute perdagangan darat yang disebut dengan New Silk Road Economic Belt dan rute perdagangan laut yang disebut dengan 21st Century Maritime Silk Road. Konsep New Silk Road Economic Belt diperkenalkan Presiden Xi Jinping pada saat melakukan kunjungan kenegaraan pertamanya ke negara Kazakhstan di 2013. Jalur perdagangan darat ini dimulai dari wilayah Xi' an di Cina, daratan Asia Tengah, Rusia hingga mencapai Jerman (Jetin, 2017). Berikut ini peta One Belt One Road Cina / Belt Road Initiative Cina yang menggambarkan jalur darat dan jalur maritim.

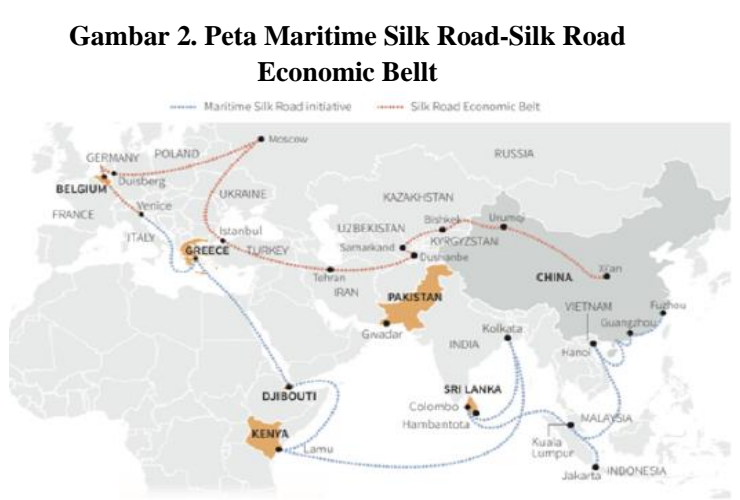

Sumber : Reuteurs, 2017.

Konsep 21st Century Maritime Silk Road atau Jalur Sutera Maritim abad 21 diumumkan Presiden Xi Jinping pada saat mengunjungi Indonesia pada Oktober 2013 (Lei, 2018). Jalur ini dibangun dalam rangka untuk menguatkan diplomasi Cina dengan kawasan Asia Selatan dan Asia Tenggara yang berfokus kepada perdagangan laut (Kartini, 2015 dalam Samti Wira Wibawati, et.al, 2018). 21st Century Maritime Silk Road akan menggabungkan kawasan pesisir tenggara Cina - Fuzhou dan Quanzhou di Provinsi Fujian, Guangzhou dan Zhanjiang di Guangdong, Beihai di Guangxi dan Haikou di Hainan - ke Eropa melewati Laut Cina Selatan dan Samudera Hindia dalam satu jalur, dan Pasifik Selatan di jalur yang lain. Dari Hanoi, Vietnam jalur laut menuju Laut Cina Selatan dan kemudian Selat Malaka untuk menuju Kuala Lumpur. Kemudian bergabung dengan Jakarta, Indonesia, sebelum menyeberangi Kolombo, Sri Lanka dan Kolkata, India.Setelah itu mengarah ke Nairobi, Kenya dan terus ke utara ke Laut Merah dan Laut Mediterania untuk mencapai Athena, Yunani sebelum selesai di Venezia (Mingjiang, 2015 dalam Samti Wira Wibawati, et.al, 2018).

\section{Hegemoni Cina di Asia Tenggara.}

Keinginan Cina untuk dapat menguasai dunia mulai dipertunjukan setahap demi setahap. Melalui BRI Cina 
menancapkan pengaruhnya di berbagai belahan dunia, salah satu kawasan yang mulai dicoba untuk dikuasai di dunia adalah kawasan Asia Tenggara.

Hegemoni Cina di kawasan Asia Tenggara ditandai dengan hadirnya BRI Cina. Sampai dengan tahun 2016, menurut CEO HSBC Malaysia, Mukhtar Hussain, proyek BRI telah tersebar ke delapan negara ASEAN dengan nilai investasi $\$ 1.77$ milliar dalam bentuk 300 perusahaan Cina yang dibangun di 26 zona kerja sama ekonomi (The Star Cina, 2017).

Ada beberapa alasan yang kuat menjadikan Asia Tenggara sebagai target investasinya. Pertama, Asia Tenggara merupakan tempat tinggal bagi tidak kurang dari 600 juta penduduk yang sekitar separuhnya berusia 30 tahun. Bagi pemerintah Cina secara ekonomi kawasan Asia Tenggara adalah pasar yang sedang tumbuh besar yang menyediakan buruh murah yang tentu menarik perhatian kalangan industri negeri panda tersebut (Edward $\mathrm{Ng}, 2017$ ).

Kedua, terjadinya peningkatan ekonomi yang kuat dalam kurun waktu beberapa tahun terakhir membantu meningkatkan jumlah kelas menengah di Asia Tenggara. Cina melihat peluang besar untuk membangun infrastruktur Asia Tenggara karena kalangan kelas menengah pada umumnya cenderung tinggal di kawasan perkotaan yang sudah tentu membutuhkan sarana transportasi yang bagus dan modern. Perkembangan Asia Tenggara ini merupakan daya tarik bagi investasi yang sedang dikembangkan BRI.

Ketiga,pemerintah-pemerintah anggota ASEAN pada umumnya telah menjalankan beberapa kebijakan yang fokus pada upaya memperbaiki iklim usaha di masing-masing negara. Kebijakan untuk menyederhanakan sistem perpajakan atau penurunan pajak korporat membantu ASEAN menarik lebih banyak investor.

\section{Program BRI Cina di Indonesia.}

Indonesia adalah salah satu negara yang mendapat perhatian Cina dalam pengembangan proyek BRI. Paling tidak, Indonesia dipilih sebagai tempat untuk mengumumkan Maritime Silk Road oleh Presiden Xi Jinping pada saat setelah mendeklarasikan proyek Silk Road di Kazakhstan beberapa bulan sebelumnya. Indonesi dipilih karena merupakan ekonomi terbesar di Asia Tenggara, kaya dengan sumber daya alam, dan lemah dalam hal pembangunan infrastruktur. Kebutuhan Cina akan sumber daya alam dan besarnya kekuatan ekonomi Cina membuat negara tirai bambu ini tertarik untuk menanamkan investasinya di Indonesia (HKTDC, 2017 dalam Bambang Sucipto, 2018: 168).

Menurut Bappenas dalam kurun waktu 2015-2020 Indonesia membutuhkan dana sebanyak $\$ 600$ miliar untuk membangun dan memperbaiki infrastruktur guna mendukung kelancaran perekonomian nasional. Sementara Indonesia hanya memiliki $25 \%$ dari seluruh dana yang dibutuhkan. Kenyataan ini membuat investasi asing sangat dibutuhkan (Bambang Sucipto, 2018: 169).

Cina memberikan penawaran pemberian dana yang sangat besar dalam rangka mendanai proyek infrastruktur hingga 90\% dari kebutuhan biayanya. Besarnya investasi yang ditawarkan oleh Presiden Xi Jinping akan mendukung Presiden Indonesia Joko Widodo dalam mewujudkan Poros Maritim Dunia. Pembangunan infrastruktur dengan tujuan peningkatan konektivitas laut dapat dilakukan dengan pembangunan pelabuhan-pelabuhan dan tol laut. Pelabuhan utama di sepanjang 21st Century Maritime Silk Road akan memiliki peran sebagai sea post yang 
melayani kargo dan kapal, serta memasok kebutuhan sumber daya manusia. Proyek pembangunan infrastruktur yang ditawarkan melalui skema jalur sutra maritim di Indonesia antara lain pembangunan pelabuhan Kuala Tanjung di Sumatera Utara dan Pelabuhan Bitung di Sulawesi Utara. Pembangunan kedua pelabuhan tersebut bertujuan untuk pemerataan perekonomian antar daerah, khususnya di luar Pulau Jawa (Muhammad Fahrizal, 2019:90)

Tidak hanya pembangunan pelabuhan, yang didanai oleh Cina melalui BRI ada juga pembangunan tol laut. Tol laut ditujukan untuk mampu meringankan biaya logistik perdagangan antar daerah ke seluruh penjuru nusantara.

Dalam KTT Kerja Sama Ekonomi Asia Pasifik (APEC) di Beijing pada tahun 2014 lalu, Presiden Joko Widodo berkomitmen dalam menghubungkan Tol Laut Indonesia dengan Jalur Sutra abad ke-21 Cina sebagai Poros Maritim Dunia. Pilihan konsep Presiden Joko Widodo mengikutsertakan Indonesia menjadi bagian dari Jalur Sutera Cina dalam APEC 2014 mendapat dukungan dari berbagai peserta kongres, yakni jalur sutra, terdiri dari jalur darat dan jalur laut, adalah rute tata niaga yang mempertemukan Eropa ke Asia Tengah dan Asia Timur, serta tata niaga dan jalur energi dari Afrika ke Asia Selatan dan Asia Timur (Andi I Burhanuddin, 2015: 19)

\section{Kepentingan Nasional Indonesia dalam Kebijakan Belt and Road Initiative Cina.}

Kepentingan Nasional (raison d'Etat) adalah tujuan dan ambisi negara, baik ekonomi, militer atau budaya. Menurut studi Hubungan Internasional, konsep ini penting sebagai dasar bagi negara dalam melakukan hubungan internasional (Intermestic Journal of International Studies, 2018).
Diawali pada saat berakhirnya era kolonisasi tahun 1960 dan perang dingin tahun 1989, era baru telah memunculkan kekuasaan aktor nonnegara, yaitu manusia secara individu maupun kolektif (komunitas atau institusi swasta) sebagai pemberi legitimasi kebijakan negara.

William Nester menyebutkan kepentingan nasional adalah tujuantujuan (goals) yang ingin dicapai oleh semua negara, yakni kemerdekaan politik, pertumbuhan ekonomi, kelestarian budaya dan perdamaian serta tujuan-tujuan khusus yang ingin dicapai negara atas masalah-masalah (isu) tertentu (William Nester, 2001).

Semua negara di dunia termasuk Indonesia memiliki kepentingan nasional seperti yang telah disebutkan di atas, yaitu kemerdekaan politik, pembangunan ekonomi, kelestarian buday, kelestarian lingkungan dan perdamaian, dan yang paling utama adalah kelangsungan hidup negara Indonesia.

Frederich S. Pearson dan J. Martin Rochester mengatakan bahwa a ada 3 kepentingan utama yag dimiliki oleh suatu negara, yaitu :

a. Tekad kuat untuk mempertahankan

keberlangsungan hidup negara, termasuk di dalamnya adalah melindungi warga negara dan integritas wilayah;

b. Memajukan kesejahteraan ekonomi penduduknya, dan;

c. Mempertahankan hak untuk menentukan diri sendiri (kemerdekaan, kedaulatan, otonomi) mengenai sistem pemerintahan yang akan dianut dan aturan-aturan yang diberlakukan di dalam negeri. (Pearson \& Martin Rochester, 1998). 
Indonesia memiliki kepentingan nasional dalam kebijakan BRI Cina, yakni dalam upaya pembangunan infrastruktur di Indonesia. Presiden Joko Widodo dalam periode kepemimpinannya mengedepankan pembangunan di segala bidang, khususnya adalah infrastruktur dalam rangka pemerataan pembangunan nasional.

Cina dan Indonesia saat ini memiliki hubungan bilateral strategic comprehensive partnership. Menurut Dubes Cina untuk Indonesia Xiao Qian status ini tidak hanya untuk menunjukkan kedekatan hubungan kedua negara saat ini, melainkan juga merefleksikan arah kerja sama Indonesia dan Cina pada masa yang akan datang. Xiao Qian mengatakan bahwa dari sisi komprehensif, kerja sama bilateral dalam sektor politik, keamanan, perdagangan dan investasi, serta hubungan masyarakat dan isu global dan kawasan terus mengalami kemajuan secara berdampingan (Republika.co.id, 2018).

\section{KESIMPULAN}

Penelitian ini dapat disimpulkan oleh penulis, bahwa: Belt and Road Initiative Cina adalah soft power Cina saat ini, jika pada pemerintahan yang lampau Cina belum menerapkan soft power ini maka saat ini di era Presiden Xi Jinping Cina mencoba untuk membangun suatu kekuatan baru di dunia, menancapkan hegemoninya di kawasan Asia Tenggara. Adapun tujuannya adalah merubah pandangan dunia dan mencoba merebut status super power baru di dunia.

Dalam kaitannya dengan program BRI Cina di Indonesia, seperti yang sudah disebutkan di atas bahwa BRI selaras dengan program Poros Maritim Dunia Presiden Joko Widodo dengan tetap mengedepankan kepentingan nasional terlebih dahulu. Investasi Cina di Indonesia tidaklah salah dari sudut pandang kepentingan nasional Indonesia. Presiden Joko Widodo ingin terciptanya pemerataan pembangunan di Indonesia melalui cara investasi Cina di Indonesia, karena Indonesia sendiri belum sanggup untuk membiayai semua pembangunan infrastruktur di seluru Indonesia. Kerja sama Indonesia-Cina juga harus selalu mengedepankan kedaulatan negara, jangan sampai Indonesia terjual kepada Cina akibat investasinya di Indonesia seperti contohnya negara Srilanka.

Selain kesimpulan yang telah disampaikan penulis, penulis juga memberika saran yaitu:

1. Investasi Cina di Indonesia harus sesuai dengan peraturan perundangundangan yang berlaku;

2. Investasi Cina di Indonesia harus memperhatikan dampak negatif yang akan ditimbulkan ke depan;

3. Indonesia jangan terbuai dengan investasi yang ditawarkan Cina, haruslah tetap mengedepankan kepentingan nasional dan kedaulatan negara.

\section{DAFTAR PUSTAKA}

Ali Zezen Zainuddin, (2017). Pemikiran Hegemoni Antonio Gramsci (1891-1937) Di Italia. Jurnal YAQZHAN, Volume 3 Nomor 2. Desember.

B Jetin, (2017). One Belt One Road Initiative and ASEAN Connectivity : Synergy Issues and Potentialities. Working Paper no. 30. Institute of Asian Studies.

Burhanuddin Andi I, (2015). Mewujudkan Poros Maritim Dunia. Yogyakarta : Deepublish.

Bungin Burhan, (2020). Post Qualitative Social Research Methods. Jakarta : Kencana. 
Cai Peter, (2017). Understanding China's Belt and Road Initiative. Lowy Institute for International Policy.

Fahrizal Muhammad, et.al, (2019). Implementasi Konsep Kebijakan One Belt One Road (OBOR) China Dalam Kerangka Kerja Sama Pembangunan Infrastruktur Di Indonesia. Journal of Diplomacy and International Studies. $\quad$ P-ISSN: 2656-3878. https://journal.uir.ac.id/index.php/j dis/index.

Gunawan Imam, (2013). Metode Penelitian Kualitatif Teori dan Praktik. Jakarta : Bumi Aksara.

Ikbar Yanuar, (2007). Ekonomi Politik Internasional 2. Bandung: PT. Refika Aditama.

Khaerani Bannati, et.al, (2019). Politik Luar Negeri Indonesia Dalam Belt and Road Initiative (BRI) Republik Rakyat Tiongkok. Prosiding Senas POLHI ke-2 Tahun 2019.

Nester William, (2001). "International Relations: Politics and Economics in the 21st Century". Belmont, CA: Wadsworth.

$\mathrm{Ng}$ Edward, (2017). The Rise of Chinese FDI into ASEAN. Nikko AM.

https://en.nikkoam.com/articles/20

17/10/the-rise-of -chinese-fdi-intoasean.

Nye Joseph S, (2008). Public Diplomacy and Soft Power. The ANNALS of the American Academy of Political and Social Science. Vol 616.

Kyoto Review, (2014). Diplomasi "Soft Power" Cina dan Kebijakan "Constructive Engagement" ASEAN : Hubungan Sino-ASEAN dan Laut Cina Selatan. https://kyotoreview.org/issue15/diplomasi-soft-power-cina-dankebijakan-constructive- engagement-asean-hubungan-sinoasean-dan-laut-cina-selatan.

Madu Ludiro, (2020). Membendung Hegemoni China di Asia Tenggara. Geotimes, Senin 26 Oktober 2020.

Pearson Frederick J \& Martin J Rochester, (1998). International Relations: The Global Condition in the Twenty First Century. New York : McGraw-Hill.

Putri Sindy Y dan Dairatul Ma'arif, (2019). Kerja Sama EkonomiPolitik Indonesia dan Cina pada Implementasi Program Belt and Road Initiative. Jurnal Kajian Lemhannas RI, edisi 39. September.

Republika.co.id, 2018. "Sejauh Mana Hubungan RI-Cina? Begini Penuturan Dubes Cina”. Rabu, 28 November 2018. https://internasional.republika.co.id /berita/piv4yv320/sejauh-manahubungan-ricina-begini-penuturandubes-cina

S Nuraeni, et.al, (2017). Regionalisme Dalam Studi Hubungan Internasional. Yogyakarta: Pustaka Pelajar.

Simon Roger, (1999). Gagasan-gagasan Politik Gramsci. Yogyakarta: Pustaka Pelajar dan Insist.

Sucipto Bambang, (2018). Strategi China Merebut Status Super Power. Yogyakarta : Pustaka Pelajar.

T. Wei.L, (2016). Introduction in H.CY Lim Tai Wei. China's One Belt One Road Initiative. London: Imperial College Press.

The Star, (2017). China's BRI seen Boosting Trade with ASEAN to US\$2.1 trilliun. https://www.thestar.com.my/busine ss/businessnews/2017/05/20/chinas-bri-seenboosting-trade-with-asean-to-us 21 trillion/ 
Vineles Phidel, (2019). Proyek Sabuk dan Jalan Cina Berhasil di Asia Tenggara, Ini Caranya. https://www.matamatapolitik.com/an alisis-menjadikan-proyek-sabuk-danjalan-china-berfungsi-di-asiatenggara/

Wibawa Samti Wira, et.al, (2018). Potensi dan Tantangan One Belt One Road (OBOR) Bagi Kepentingan Nasional Indonesia Di Bidang Maritim. Jurnal Kajan Wilayah LIPI Nomor.9 P-ISSN:2087-2119.

Wijaya Handriyanto, 2020.Aktualisasi Kebijakan China One Belt One Road Di Indonesia Melalui Pembangunan Kereta Cepat Jakarta-Bandung. Jurnal Dinamika Global Vol.5. No. 1. Juni

$\mathrm{X} \mathrm{Li}$, (2015). Interpreting and Understanding "The Chinese Dream" in a Holistic Nexus. Fudan University. J.Hum, Soc

Yani Yanyan M \& Elnovani Lusiana, (2018). Soft Power dan Soft Diplomacy. Jurnal TAPIs Vol.14 No.02, Juli-Desember 2018. 